\title{
PENILAIAN PELAKSANAAN USAHA KESEHATAN SEKOLAH DASAR DI KABUPATEN PESISIR SELATAN
}

\author{
Rosmaneli $^{1}$, Yaslindo ${ }^{2}$, Kibadra $^{3}$ \\ Jurusan Pendidikan Olahraga Prodi. Pendidikan Jasmani Kesehatan dan Rekreasi Fakultas Ilmu \\ Keolahragaan. Jalan Prof. Dr. Hamka Air Tawar Barat, Padang 25132, Indonesia Universitas Negeri \\ Padang \\ Email; rosmaneli@fik.unp.ac.id ${ }^{1}$, yaslindo@fik.unp.ac.id ${ }^{2}$, kibadra@fik.unp.ac.id ${ }^{3}$
}

Abstrak

Beberapa sekolah masih ada yang belum menjalankan kegiatan UKS sesuai dengan yang seharusnya. Disebabkan oleh beberapa faktor seperti kurangnya pemahaman guru mengenai pelaksanaan kegiatan usaha kesehatan sekolah (UKS) di sekolah dasar serta belum pernah guru tersebut mengikuti sosialisasi tentang kegiatan usaha kesehatan sekolah (UKS) di sekolah dasar. Jenis penelitian ini adalah kuantitatif dengan mengunakan metode deskriptif yang bertujuan untuk mengetahui Penilaian Pelaksanaan Usaha Kesehatan Sekolah Dasar di Kabupaten Pesisir Selatan (Studi Kasus di Sekolah Dasar Negeri). Instrument dalam penelitian ini adalahdengan cara peneliti menilai/mengisi angket pengamatan/lembar observasi yang sesuai penilaian UKS yang dikeluarkan oleh Kementrian Kesehatan bekerja sama dengan berbagai kementrian dalam bentuk kegiatan lintas sektor sehingga bisa menyebabkan informasi yang lebih objektif dari responden. Teknik pengambilan sampel dilakukan dengan cara Purposive Sampling, dari 45 sekolah dasar menjadi 30 sekolah dasar (dua sekolah untuk satu kecamatan). Hasil penelitian diperoleh dari rata-rata jawaban penelitian masing-masing variabel dari Penilaian Pelaksanaan Usaha Kesehatan Sekolah Dasar di Kabupaten Pesisir Selatan (Studi Kasus di Sekolah Dasar Negeri) dengan tingkat pencapaian sebesar 55,72\% dan termasuk interpretasi cukup.

Kata Kunci : Pelaksanaan Usaha Kesehatan Sekolah

\section{ASSESSMENT OF BASIC SCHOOL HEALTH BUSINESS IMPLEMENTATION KABUPATEN PESISIR SELATAN}

\section{Abstract \\ Some schools still do not carry out UKS activities as they should. Caused by several factors} such as a lack of teacher understanding of the implementation of school health business activities $(U K S)$ in elementary schools and the teacher had never attended a socialization of school health business activities (UKS) in elementary schools. The type of this research is quantitative by using descriptive method which aims to determine the Assessment of the Implementation of Primary School Health Enterprises in Pesisir Selatan District (Case Study in Public Elementary Schools). The instrument in this study is the way researchers assess / fill out observation questionnaires / observation sheets that are in accordance with the UKS assessment issued by the Ministry of Health in collaboration with various ministries in the form of cross-sectoral activities so as to cause more objective information from respondents. The sampling technique was carried out by purposive sampling, from 45 primary schools to 30 primary schools (two schools for one sub-district). The results of the study were obtained from the average research responses of each variable from the Evaluation of the Implementation of Primary School Health Enterprises in Pesisir Selatan District (Case Study in Public Elementary Schools) with an achievement rate of 55.72\% and including sufficient interpretation.

Keywords : Implementation of School Health Business

\section{PENDAHULUAN}

Program Usaha Kesehatan Sekolah (UKS), berorientasi kepada masyarakat sekolah, mulai pendidikan dasar sampai pendidikan menengah. Oleh karena masyarakat sekolah sangat mudah untuk dikelola dan terorganisir, serta memiliki rentangan waktu yang dapat dikontrol. Masyarakat sekolah merupakan masyarakat yang dinamis, baik secara fisik maupun intelektual. 
Pelaksanaan UKS di sekolah didasari dengan keputusan tiga kementrian, yaitu Kementrian Dalam Negeri, Kementrian Pendidikan Nasional, dan Kementrian Agama. Sampai saat sekarang keputusan tersebut masih dipakai, dan dipertahankan. Keunggulan dari kegiatan ini dapat mendidik dan mengembangkan pribadi peserta didik untuk dapat mengetahui pentingnya gaya hidup sehat dari usia dini. Sesuai dengan motto kesehatan bahwa "tindak preventif lebih baik kuratif". Artinya penjagaan kesehatan akan lebih baik dibanding dengan pengobatan. Olah karena unit cost untuk pengobatan jauh lebih tinggi dibanding tindakan pemeliharaan kesehatan.

Pelaksanan UKS di SDN, dikenal dengan

Trias UKS (tiga pokok program). Program tersebut adalah pendidikan kesehatan, pelayanan kesehatan dan lingkungan sekolah yang sehat. Pendidikan kesehatan berkaitan dengan, membiasakan pola hidup sehat dari usia dini peserta didik melalui materi mata pelajaran IPA dan Penjasorkes. Untuk pelayanan kesehatan pihak sekolah bekerja sama dengan pihak Puskesmas yang terdekat dari sekolah. Petugas Puskesmas mendatang sekolah secara berkala untuk melakukan pemeriksaan kesehatan, imunisasi, kesehatan pribadi serta pertumbuhan dan perkembangan gizi peserta didik. Sedangkan lingkungan sekolah yang sehat berkenaan dengan kesehatan lingkungan, gedung sekolah, kebun sekolah, dan sosial masyarakat sekolah. Semua kegiatan yang disampaikan di atas harus terlaksana sesuai dengan panduan yang dikeluarkan Kementrian Kesehatan. Untuk itu bagaimana pelaksanan pendidikan kesehatan?, bagaimana pelayanan kesehatan dan bagaimana lingkungan sekolah yang sehat.

\section{TUJUAN, LUARAN, DAN KONSTRIBUSI PENELITIAN}

1. Tujuan Penelitian ini adalah untuk melihat Bertujuan untuk mengetahui sejauhmana pelaksanaan pendidikan kesehatan yang dilakukan di sekolah, pendidikan kesehatan yang dilakukan oleh sekolah dan untuk mengetahui linmgkungan sekolah yang sehat. Berdasarkan tujuan yang ingin dicapai, maka dilakukan pendekatan peningkatan pengetahuan guru yang ditugaskan oleh sekolah sebagai guru pembina UKS, cara menilai kesehatan dan gizi anak sekolah, dan mensosialisasikan tentang lingkungan sekolah yang sehat.
2. Luaran dari penelitian adalah hasil penelitian ini akan dipublikasikan pada jurnal Sport Science, Manssana, Saintika, dan Performa Olahraga Fakultas Ilmu Keolahragaan Universitas Negeri Padang tahun 2017 dan juga digunakan sebagai tambahan pada bahan ajar pada mata kuliah Pendidikan Kesehatan, Perencanaan dan Telaah kurikulum, Strategi Pembelajaran, dan Micro Teaching.

3. Kontribusi Penelitian adalah diharapkan dengan penelitian ini memberikan kontribusi untuk sekolah dalam upaya pengembangan UKS di sekolah.

\section{METODE PENELITIAN}

Penelitian ini termasuk penelitian deskriptif yaitu penelitian.

Populasi dalam penelitian ini adalah SD Negeri di Kabupaten Pesisir Selatan sebanyak 45 SD Negeri.

Teknik pengambilan sampel dilakukan dengan menggunakan teknik Purpossive Sampling, adalah30 SD Negeri (dua sekolah untuk satu kecamatan) yang ada di Kabupaten Pesisir Selatan.

Instrument yang digunakan adalah lembar observasi yang disusun dan dirancang untuk mendapatkan data tentang pelaksanaan Pelaksanaan Kegiatan Usaha Kesehatan Sekolah (UKS) sesuai dengan penilaian UKS yang dikeluarkan oleh Kementrian Kesehatan bekerja sama dengan berbagai kementrian dalam bentuk kegiatan lintas sektor, sehingga lembar pengamatan yang digunakan dalam penelitian ini telah dinyatakan valid.

\section{HASIL PENELITIAN DAN PEMBAHASAN 1. Pendidikan Kesehatan}

Data tentang variabel pendidikan kesehatan terhadap Penilaian Pelaksanaan Usaha Kesehatan Sekolah Dasar di Kabupaten Pesisir Selatan dari nomor 92 sampai 98 item/butir pernyataan terhadap 30 Sekolah Dasar sebagai objek yang diamati. Data dikelompokan masingmasing jawaban berdasarkan nilai skor dan data dihitung persentasenya, maka dapat dibuat rangkuman distribusi frekwensi variabel pendidikan kesehatan pada tabel berikut :

Tabel 2

Distribusi Frekwensi Variabel Pendidikan Kesehatan

\begin{tabular}{|c|c|c|c|}
\hline No & Kelas Interval & $\begin{array}{c}\text { Frekuensi } \\
\text { Absolut } \\
\text { (Fa) }\end{array}$ & $\begin{array}{c}\text { Frekuensi } \\
\text { Relatif } \\
\text { (Fr) }\end{array}$ \\
\hline 1 & $48,80-53,80$ & 18 & 60,00 \\
\hline
\end{tabular}




\begin{tabular}{|c|l|c|c|}
\hline 2 & $53,81-58,81$ & 9 & 30,00 \\
\hline 3 & $58,82-63,82$ & 1 & 3,33 \\
\hline 4 & $63,83-68,83$ & 1 & 3,33 \\
\hline 5 & $68,84-73,84$ & 1 & 3,33 \\
\hline & Jumlah & 30 & $100 \%$ \\
\hline & Berdasarkan pada tabel & distribusi \\
\hline
\end{tabular}

frekuensi di atas dari 30 Sekolah Dasar, ternyata sebanyak 18 Sekolah Dasar (60\%) dengan kelas interval 48,80 - 53,80, kemudian sebanyak 9 Sekolah Dasar (30\%) dengan kelas interval 53,81 - 58,81, lalu sebanyak 1 Sekolah Dasar $(3,33 \%)$ dengan kelas interval 58,82 - 63,82, sedangkan sebanyak 1 Sekolah Dasar $(3,33 \%)$ dengan kelas interval 63,83 - 68,83 dan sisanya ada 1 Sekolah Dasar lagi $(3,33 \%)$ dengan kelas interval 68,84 73,84 . Untuk lebih jelasnya dapat dilihat pada histogram berikut:

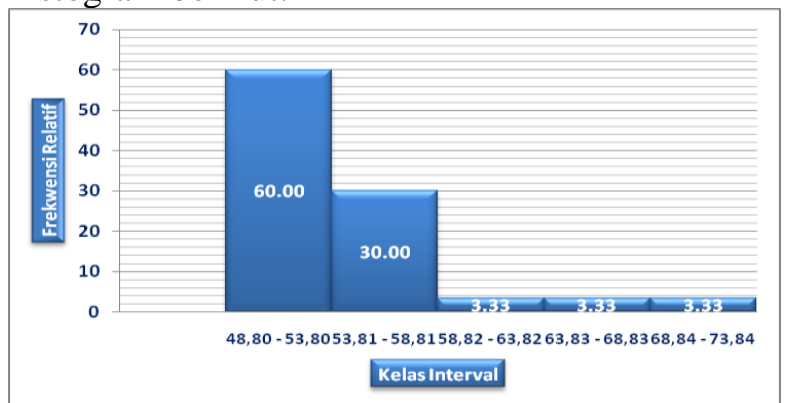

Histogram 1. Distribusi Frekwensi Variabel Pendidikan Kesehatan

\section{Pelayanan Kesehatan}

Data tentang variabel pelayanan kesehatan terhadap Penilaian Pelaksanaan Usaha Kesehatan Sekolah Dasar di Kabupaten Pesisir Selatan dari nomor 99 sampai 103 item/butir pernyataan terhadap 30 Sekolah Dasar sebagai objek yang diamati. Data dikelompokan masingmasing jawaban berdasarkan nilai skor dan data dihitung persentasenya, maka dapat dibuat rangkuman distribusi frekwensi variabel pelayanan kesehatan pada tabel berikut :

Tabel 3

Distribusi Frekwensi Variabel Pelayanan Kesehatan

\begin{tabular}{|c|c|c|c|}
\hline No & Kelas Interval & $\begin{array}{c}\text { Frekuensi } \\
\text { Absolut } \\
\text { (Fa) }\end{array}$ & $\begin{array}{c}\text { Frekuensi } \\
\text { Relatif } \\
\text { (Fr) }\end{array}$ \\
\hline 1 & $53,16-57,16$ & 17 & 56,67 \\
\hline 2 & $57,17-61,17$ & 7 & 23,33 \\
\hline 3 & $61,18-65,18$ & 3 & 10,00 \\
\hline 4 & $65,19-69,19$ & 2 & 6,67 \\
\hline 5 & $69,16-73,20$ & 1 & 3,33 \\
\hline & Jumlah & 30 & $100 \%$ \\
\hline
\end{tabular}

frekuensi di atas dari 30 Sekolah Dasar, ternyata sebanyak 17 Sekolah Dasar $(56,67 \%)$ dengan kelas interval 53,16 - 57,16, kemudian sebanyak 7 Sekolah Dasar $(23,33 \%)$ dengan kelas interval 57,17 - 61,17, lalu sebanyak 3 Sekolah Dasar (10\%) dengan kelas interval 61,18 - 65,18, sedangkan sebanyak 2 Sekolah Dasar $(6,67 \%)$ dengan kelas interval 65,19 - 69,19 dan sisanya ada 1 Sekolah Dasar lagi $(3,33 \%)$ dengan kelas interval 69,16 - 73,20. Untuk lebih jelasnya dapat dilihat pada histogram berikut:

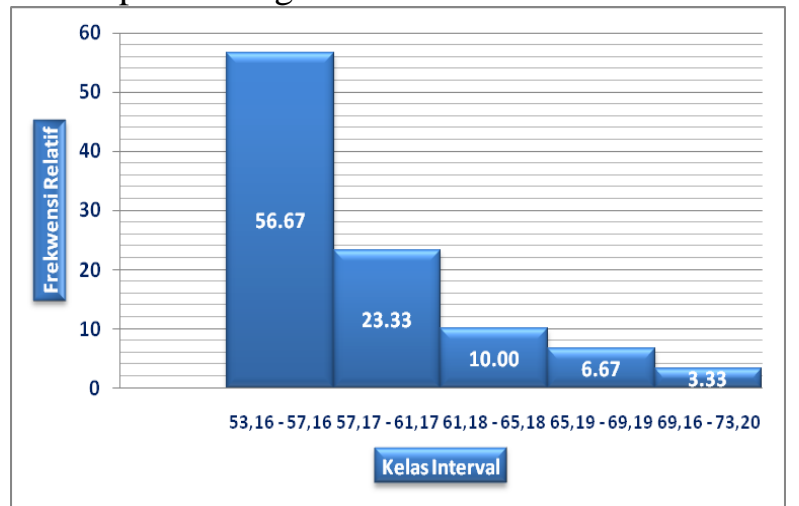

\section{Histogram 2. Distribusi Frekwensi Variabel Pelayanan Kesehatan}

\section{Pembinaan Lingkungan Sekolah Sehat}

Data tentang variabel pembinaan lingkungan sekolah sehat terhadap Penilaian Pelaksanaan Usaha Kesehatan Sekolah Dasar di Kabupaten Pesisir Selatan dari nomor 1 sampai 91 item/butir pernyataan terhadap 30 Sekolah Dasar sebagai objek yang diamati. Data dikelompokan masing-masing jawaban berdasarkan nilai skor dan data dihitung persentasenya, maka dapat dibuat rangkuman distribusi frekwensi variabel pembinaan lingkungan sekolah sehat pada tabel berikut :

\section{Tabel 4}

Distribusi Frekwensi Variabel Pembinaan Lingkungan Sekolah Sehat

\begin{tabular}{|c|c|c|c|}
\hline No & Kelas Interval & $\begin{array}{c}\text { Frekuensi } \\
\text { Absolut } \\
\text { (Fa) }\end{array}$ & $\begin{array}{c}\text { Frekuensi } \\
\text { Relatif } \\
\text { (Fr) }\end{array}$ \\
\hline 1 & $49,66-53,66$ & 8 & 26,67 \\
\hline 2 & $53,67-57,67$ & 16 & 53,33 \\
\hline 3 & $57,68-61,68$ & 4 & 13,33 \\
\hline 4 & $61,69-65,69$ & 1 & 3,33 \\
\hline 5 & $65,70-69,70$ & 1 & 3,33 \\
\hline \multicolumn{2}{|r|}{ Jumlah } & 6 & $100 \%$ \\
\hline
\end{tabular}

frekuensi di atas dari 30 Sekolah Dasar, ternyata sebanyak 8 Sekolah Dasar (26,67\%) dengan kelas interval 49,66 - 53,66, kemudian sebanyak 16 Sekolah Dasar $(53,33 \%)$ dengan kelas interval 53,67 - 57,67, lalu sebanyak 4 Sekolah Dasar $(13,33 \%)$ dengan kelas interval 57,68 - 61,68, sedangkan sebanyak 1 Sekolah Dasar $(3,33 \%)$ 
dengan kelas interval 61,69 - 65,69 dan sisanya ada 1 Sekolah Dasar lagi (3,33\%) dengan kelas interval 65,70 - 69,70. Untuk lebih jelasnya dapat dilihat pada histogram berikut:

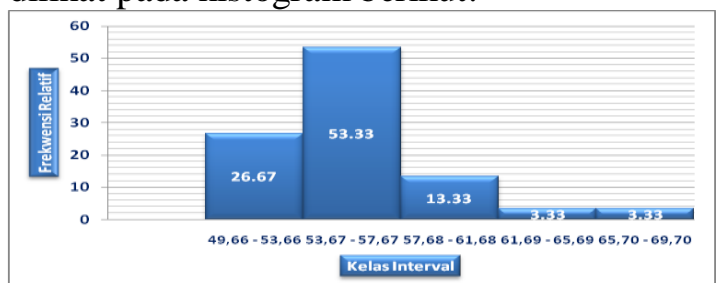

Histogram 3. Distribusi Frekwensi Variabel Pembinaan Lingkungan Sekolah Sehat

4. Penilaian Pelaksanaan Usaha Kesehatan Sekolah Dasar di Kabupaten Pesisir Selatan (Studi Kasus di Sekolah Dasar Negeri)

Data tentang variabel Penilaian Pelaksanaan Usaha Kesehatan Sekolah Dasar di Kabupaten Pesisir Selatan dari nomor 1 sampai 103 item/butir pernyataan terhadap 30 Sekolah Dasar sebagai objek yang diamati. Data dikelompokan masing-masing jawaban berdasarkan nilai skor dan data dihitung persentasenya, maka dapat dibuat rangkuman distribusi frekwensi variabel Penilaian Pelaksanaan Usaha Kesehatan Sekolah Dasar pada tabel berikut :

\section{Tabel 5}

Distribusi Frekwensi Variabel Penilaian Pelaksanaan Usaha Kesehatan Sekolah Dasar

\begin{tabular}{|c|c|c|c|}
\hline No & $\begin{array}{c}\text { Kelas } \\
\text { Interval }\end{array}$ & $\begin{array}{c}\text { Frekuensi } \\
\text { Absolut } \\
\text { (Fa) }\end{array}$ & $\begin{array}{c}\text { Frekuensi } \\
\text { Relatif } \\
\text { (Fr) }\end{array}$ \\
\hline 1 & $51,17-55,17$ & 15 & 50,00 \\
\hline 2 & $55,18-59,18$ & 9 & 30,00 \\
\hline 3 & $59,19-63,19$ & 3 & 10,00 \\
\hline 4 & $63,20-67,20$ & 2 & 6,67 \\
\hline 5 & $67,21-71,21$ & 1 & 3,33 \\
\hline \multicolumn{2}{|r|}{ Jumlah } & 30 & $100 \%$ \\
\hline
\end{tabular}

frekuensi di atas dari 30 Sekolah Dasar, ternyata sebanyak 15 Sekolah Dasar (50\%) dengan kelas interval 51,17 - 55,17, kemudian sebanyak 9 Sekolah Dasar (30\%) dengan kelas interval 55,18 - 59,18, lalu sebanyak 3 Sekolah Dasar (10\%) dengan kelas interval 59,19 - 63,19, sedangkan sebanyak 2 Sekolah Dasar $(6,67 \%)$ dengan kelas interval 63,20 - 67,20 dan sisanya ada 1 Sekolah Dasar Negeri lagi $(3,33 \%)$ dengan kelas interval 67,21 - 71,21. Untuk lebih jelasnya dapat dilihat pada histogram berikut:

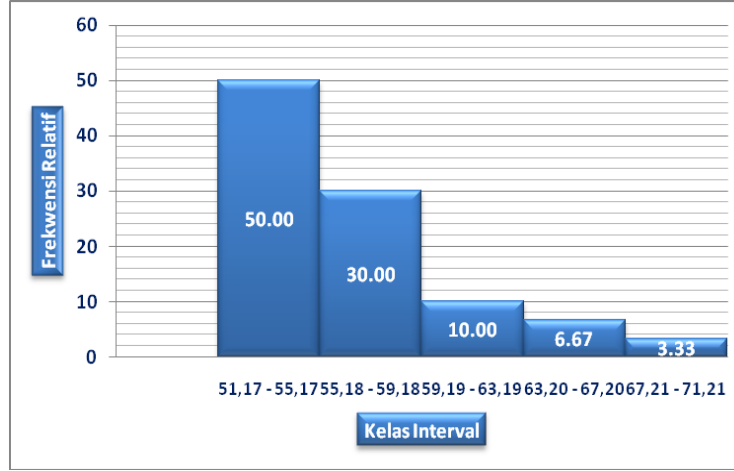

Histogram 4. Distribusi Frekwensi Variabel Penilaian Pelaksanaan Usaha Kesehatan Sekolah Dasar

\section{Pembahasan}

Berdasarkan hasil pengamatan terhadap 30 Sekolah Dasar yang berhubungan dengan Pelaksanaan Kegiatan Usaha Kesehatan Sekolah (UKS) di Sekolah Dasar Kabupaten Pesisir Selatan, tingkat pencapaian sebesar 55,67\% dan termasuk interpretasi cukup. Klasifikasi ini berdasarkan interprestasi skor untuk menyimpulkan hasil penelitian.

Hasil pengamatan terhadap 30 Sekolah Dasar tentang Pelaksanaan Kegiatan Usaha Kesehatan Sekolah (UKS) di Sekolah Dasar Kabupaten Pesisir Selatan jika dibandingkan dengan interprestasi skor untuk menyimpulkan hasil penelitian, maka dapat ditentukan bahwa dari 30 Sekolah Dasar, ternyata tidak ada Sekolah Dasar memiliki interprestasi skor pada kategori sangat lemah, kemudian tidak ada Sekolah Dasar memiliki interprestasi skor pada kategori lemah, lalu sebanyak 27 Sekolah Dasar memiliki interprestasi skor pada kategori cukup, sedangkan sebanyak 3 Sekolah Dasar memiliki interprestasi skor pada kategori kuat dan sisanya tidak ada Sekolah Dasar memiliki interprestasi skor pada kategori sangat kuat.

Diharapkan Pelaksanaan Kegiatan Usaha Kesehatan Sekolah (UKS) di Sekolah Dasar Kabupaten Pesisir Selatan dapat ditingkatkan, agar Pelaksanaan Kegiatan Usaha Kesehatan Sekolah (UKS) di Sekolah Dasar Kabupaten Pesisir Selatan yang diharapkan lebih tercapai. Keanggotaan tim pelaksana Kegiatan Usaha Kesehatan Sekolah (UKS) di Sekolah ditetapkan oleh Kepala Sekolah. Keanggotaannya terdiri dari unsur pemerintah desa/kelurahan, kepala sekolah, guru, pamong belajar, Organisasi Siswa Intra Sekolah (OSIS), puskesmas, orang tua murid, serta unsur lain yang relevan.

\section{SIMPULAN}

Data tentang variabel Pelaksanaan Usaha Kesehatan Sekolah Dasar di Kabupaten Pesisir 
Selatan dari nomor 1 sampai 103 item/butir pernyataan terhadap 30 Sekolah Dasar sebagai objek yang diamati, ternyata tidak ada Sekolah Dasar memiliki interprestasi skor pada kategori sangat lemah, kemudian tidak ada Sekolah Dasar memiliki interprestasi skor pada kategori lemah, lalu sebanyak 28 Sekolah Dasar memiliki interprestasi skor pada kategori cukup, sedangkan sebanyak 2 Sekolah Dasar memiliki interprestasi skor pada kategori kuat dan sisanya tidak ada Sekolah Dasar memiliki interprestasi skor pada kategori sangat kuat. Berdasarkan hasil pengamatan terhadap 30 Sekolah Dasar yang berhubungan dengan ruang UKS dengan tingkat pencapaian sebesar $55,72 \%$ dan termasuk interpretasi cukup.

\section{DAFTAR PUSTAKA}

Arikunto, Suharsimi. 2010. Prosedur Penelitian. Jakarta : Rineka Cipta.

Depkes RI. 1992. Undang-undang No. 23 Tahun 1992 Tentang Kesehatan. Jakarta: Depkes RI.

Depkes RI. 1994. Pedoman Dasar Usaha Kesehatan Sekolah. Padang: Kanwil Depkes Sumbar.

Notoatmodjo, (2012). Promosi Kesehatan Di Sekolah. Jakarta: Rineka Cipta.

Sudjana, Nana. 2002. Metoda Statistik. Bandung: Tarsito.

Sugiyono, (2012). Metode Penelitan Kuantitatif Kualitatif dan $R \& D$. Bandung: Alfabeta.

Trianto, (2011). Pengantar Penelitian Pendidikan Bagi Pengembangan Profesi Pendidikan \& Tenaga Kependidikan. Jakarta: Gramedia.

Undang-Undang RI No. 23 Tahun (1992). Tentang Kesehatan Sekolah. Jakarta: Depkes.

Undang-Undang RI No. 36 Tahun (2009). Tentang Kesehatan. Jakarta: Depkes. 